\section{A Novel Method for Rapid Micropropagation of Pineapple}

\author{
E. Kiss, J. Kiss, G. Gyulai, and L.E. Heszky ${ }^{1}$ \\ Department of Genetics and Plant Breeding, Gödöllö University of Agriculture, \\ Gödöllö, Hungary, H-2103
}

Additional index words. shoot elongation, axillary shoot induction, Ananas comosus

Abstract. A novel micropropagation method for pineapple (Ananas comosus L.), based on shoot elongation induced in vitro, was demonstrated for two cultivars. Decapitated in vitro plantlets were used as explants. Shoot etiolation was induced by placing explants in a Murashige and Skoog (MS) medium containing NAA (10 $\left.\mu_{\mathrm{M}}\right)$ and incubating in darkness at $28 \mathrm{C}$ for 30 to 40 days. The mean number of the regenerated etiolated shoots per explant was 2.6 \pm 0.29 . The etiolated shoots were placed into N6 medium supplemented with kinetin or BA ( 25 or $20 \mu_{\mathrm{M}}$, respectively). After 4 to 6 weeks, shoots regenerated along the nodes. The highest regeneration rate was 15 and 13 plantlets per node with $25 \mu \mathrm{M}$ kinetin and 20 $\mu_{\mathrm{M}}$ BA, respectively. Regenerated plantlets were rooted on a growth-regulator-free MS medium. Residual shoots of the initial explants could be recycled by rooting on a growthregulator-free MS medium. This procedure enables the regeneration of several thousand plantlets per year. Chemical names used: naphthaleneacetic acid (NAA); benzyladenine (BA).

Pineapple is one of the food plants that always has been propagated vegetatively. Traditional propagation uses various vegetative parts, organs, or tissues, such as 1) suckers originating from buds below ground level; 2) hapas, which are shoots developing at the base of the peduncle; 3) leafy branches arising from buds in leaf axils; 4) slips, which grow out of the peduncle below or at the base of fruit; 5) crowns, arising from the upper part of the fruit; and 6) butts or stumps from the mature plant (Rangan, 1984).

To our knowledge, Aghion and Beauchesne (1960) reported on the first in vitro micropropagation method; since then, numerous papers have been published on the subject. Plants were regenerated in vitro from apex or axillary buds from the crown (Fitchet, 1985; Mapes, 1973; Mathews et al., 1976), slips (Sita et al., 1974), lateral buds (Zepeda and Sagawa, 1981), syncarp (Wakasa, 1979), leaf bud (Seow and Wee, 1970), and callus (Rao et al., 1981; Wee, 1979). Some of these methods were shown to induce variations (DeWald, 1988; Wakasa, 1979). The appearance of offtypes was due mainly to somaclonal variation (Larkin and Scowcroft, 1981). Though these variants may provide advantageous characteristics, such as new leaf and fruit shape, leaf color, and spininess (Gyulai et al., 1992; Kiss et al., 1992; Skirvin, 1981), maintenance of genotypic and phenotypic identity is an indispensable requirement for mass propagation.

Using nodal segments for micropropagation and conservation of genetic stability has been demonstrated with potato (Solanum

Received for publication 22 Apr. 1994. Accepted for publication $20 \mathrm{Aug}$. 1994. The cost of publishing this paper was defrayed in part by the payment of page charges. Under postal regulations, this paper therefore must be hereby marked advertisement solely to indicate this fact.

${ }^{1}$ To whom reprint requests should be addressed. tuberosum L.) (Heszky and Nagy, 1987), alfalfa (Medicago sativa L.) (Dudits et al., 1991), and tobacco (Nicotiana tabacum L.) (Maliga et al., 1975). Our objective was to develop an in vitro method for pineapple using the concept of etiolated nodal segments.

\section{Materials and Methods}

The in vitro-preserved cultivars Cayenne de Oriental and Espanola Raja were provided as a courtesy by the Ciego de Avila Univ., Ciego de Avila, Cuba. Rooted plantlets (1 to 8 $\mathrm{cm}$ ) were placed onto MS medium (Murashige and Skoog, 1962) containing $10 \mu \mathrm{M}$ NAA and were maintained in $25-\mathrm{mm}$ culture tubes at $26 \mathrm{C}$ and a $16-\mathrm{h}$ photoperiod $\left(40 \mu \mathrm{mol} \cdot \mathrm{m}^{-2} \cdot \mathrm{s}^{-1}\right.$ photosynthetic photon flux with cool-white fluorescent tubes). On the fourth to fifth day of incubation, shoots were cut 5 to $8 \mathrm{~mm}$ above the plant base. The stumps were kept on the same medium and incubated in darkness at 28C. Etiolated shoots, developed in darkness, were harvested and placed horizontally onto an N6 medium (Chu, 1978) supplemented with various kinetin or BA concentrations ( 0 to 50 or 0 to $40 \mu \mathrm{M}$, respectively). Cultures were incubated at $26 \mathrm{C}$ and a $16-\mathrm{h}$ photoperiod in $10-\mathrm{cm}$ petri dishes. Shoots, developed from the etiolated stem segments, were rooted on a growth-regulator-free MS medium. To recycle the initial explants, residual shoots were placed

on a growth- regulator-free MS medium for

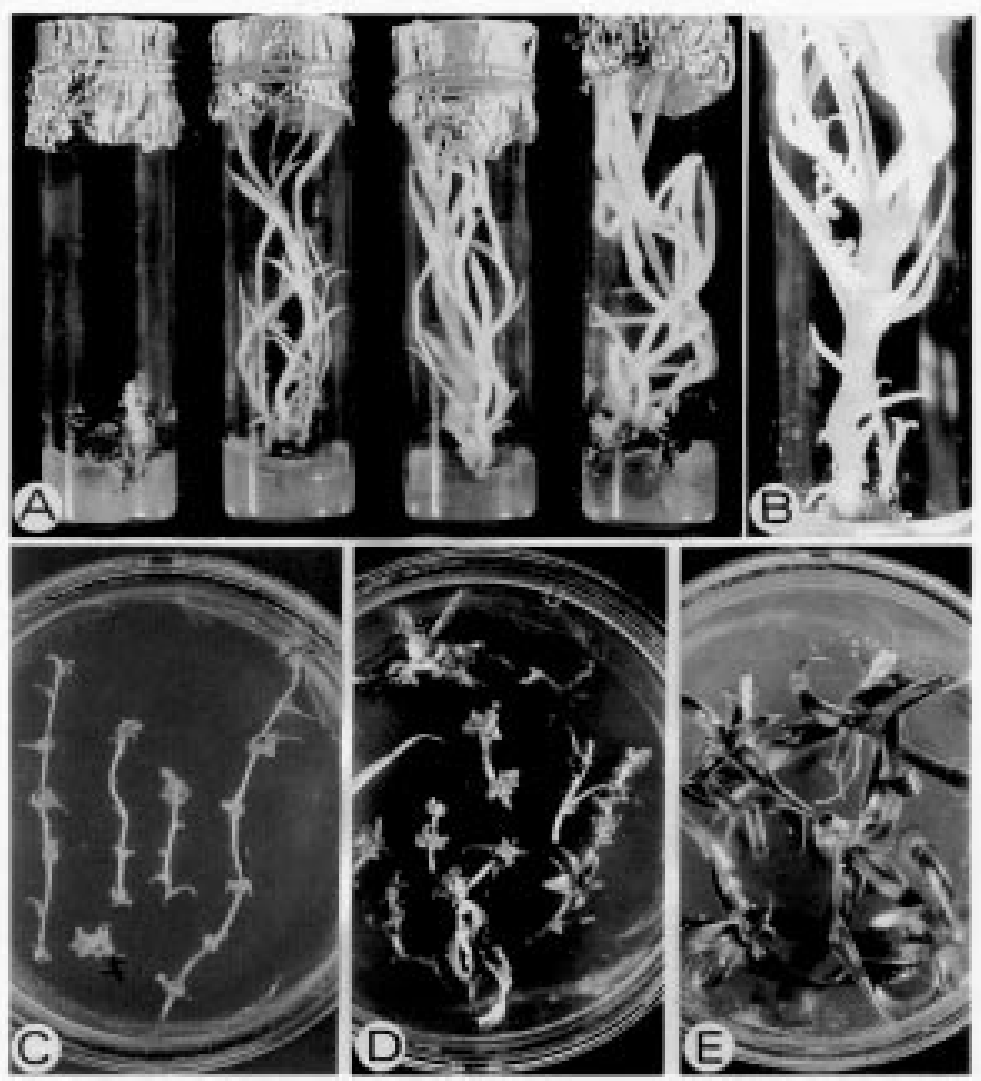

Fig. 1. In vitro shoot development in pineapple. (A) Etiolated shoots developed in darkness on MS medium supplemented with $10 \mu \mathrm{M}$ NAA after 12, 20, 30, and 40 days of incubation. (B) Swelled etiolated shoot on MS medium supplemented with $10 \mu \mathrm{M}$ NAA after 50 days of incubation (culture tube $\emptyset$ for $\mathbf{A}$ and B, $25 \mathrm{~mm}$ ). (C) Swelling nodes of etiolated shoots developed in darkness after transfer to light on N6 medium supplemented with $25 \mu \mathrm{m}$ kinetin on the 10th day of incubation. (D) Early stage of direct organogenesis from the nodal segments of etiolated shoots placed on N6 medium supplemented with 25 $\mu_{\mathrm{M}}$ kinetin after 20 days of incubation. (E) Later stage of direct organogenesis from the nodal segments of etiolated shoots placed on N6 medium supplemented with $25 \mu \mathrm{m}$ kinetin after 30 days of incubation (petri dish for $\mathbf{C}-\mathbf{E} \emptyset, 100 \mathrm{~mm}$ ). 
rooting. When plantlets reached 8 to $10 \mathrm{~cm}$ high, they were planted in sterilized soil and grown in the greenhouse.

\section{Results and Discussion}

Etiolated shoots grew from the rooted stumps after 10 to 14 days of dark incubation (Fig. 1A). Because more than one etiolated shoot per stump developed, we concluded that these were of adventitious origin. By the 30th to 35th day, shoot length had reached 6 to 10 $\mathrm{cm}$ (mean, $7.74 \pm 1.13 \mathrm{~cm}$ ) with six to nine nodes per shoot (mean, $7.37 \pm 0.88$ ). There was a strong correlation $(r=0.98)$ between the length of the initial plantlet before decapitation and the length of the etiolated shoots. Initial explants of 4 to $9 \mathrm{~cm}$ provided etiolated shoots 6.5 to $10 \mathrm{~cm}$ in length with seven nodes for subsequent cultures. Etiolated shoot development ceased after 5 to 6 weeks. In some

Table 1. Effect of kinetin and BA concentrations on the number of pineapple plantlets regenerated from each etiolated node segment on N6 medium after 30 days of incubation.

\begin{tabular}{lc}
\hline $\begin{array}{l}\text { Cytokinin } \\
(\mu \mathrm{M})\end{array}$ & $\begin{array}{c}\text { Mean no. plantlets/ } \\
\text { explant regenerated }\end{array}$ \\
\hline BA & $3.5 \pm 0.12$ \\
0 (control) & $10.2 \pm 0.08^{*}$ \\
10 & $13.3 \pm 0.12^{*}$ \\
20 & $11.9 \pm 0.19^{*}$ \\
30 & $9.1 \pm 0.12^{*}$ \\
40 & \\
Kinetin & $3.5 \pm 0.12$ \\
0 (control) & $13.3 \pm 0.12^{*}$ \\
12.5 & $14.7 \pm 0.16^{*}$ \\
25.0 & $12.6 \pm 0.09^{*}$ \\
37.5 & $10.5 \pm 0.08^{*}$ \\
50.0 &
\end{tabular}

${ }^{2}$ Mean number \pm SE $(n=25$ to 28$)$. Each explant contained seven nodes.

"Significant at $P \leq 0.05$. cases, the etiolated shoots swelled enormously (Fig. 1B), and the nodes lost their regeneration capacity.

Etiolated shoots harvested at 30 to 40 days after induction were subcultured onto N6 media containing BA and kinetin ( 0 to 40 and 0 to $50 \mu \mathrm{M})$. The shoots turned green, and the nodes swelled after 8 to 10 days (Fig. 1C). Plants regenerated at the nodes on the 18 to 20th day. The number of plantlets regenerated per node varied with the types and cytokinin concentrations used (Table 1). BA and kinetin were effective at relatively high concentrations (20 and $25 \mu \mathrm{M}$, respectively).

The developing plantlets were 3 to $5 \mathrm{~cm}$ high within 20 to 25 days (Fig. $1 \mathrm{D}$ and E); they then were separated and rooted on a growthregulator-free MS medium. Recycled plantlets were rooted in 3 to 4 weeks on the same medium. The rooted plantlets were eventually transplanted in soil and grown into the greenhouse for further analysis.

The effects of segmenting the etiolated stem also were studied using etiolated shoot segments with one to five nodes (Fig. 2). The maximum regeneration rate for stems with one or two nodes was no more than one shoot per node. This result suggests that the regenerated shoots originated from axillary buds. When segments of three or more nodes were cultured, the regeneration rate was more than one shoot per node, suggesting that some adventitious buds were produced. We saw no phenotypic heterogeneity among the regenerated plantlets in this study. This finding is contrary to other observations reported (DeWald, 1988; Rao et al., 1981; Wee, 1979). Because bromeliads are particularly prone to phenotypic variation in tissue culture, using axillary shoots in itself does not guarantee that there will be no off-types formed. Field tests are necessary to substantiate the genetic stability of the pine-

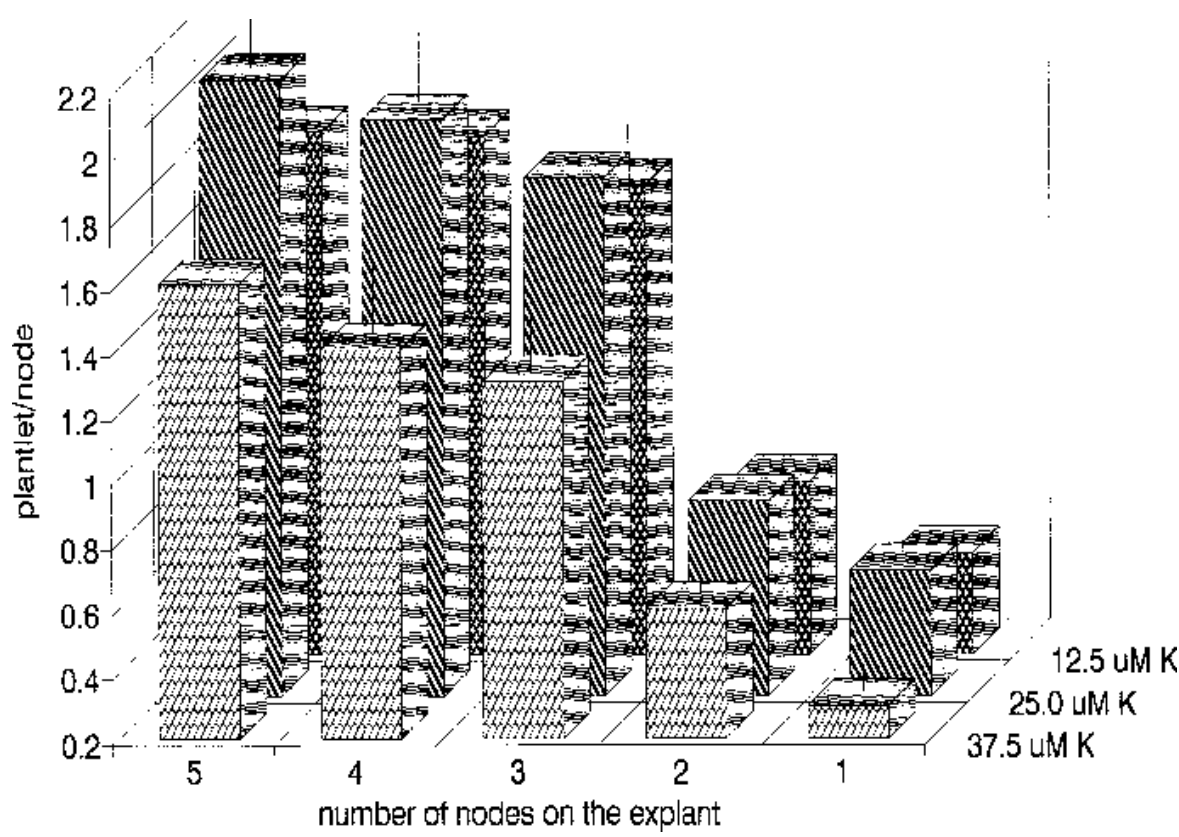

Fig. 2. Relationship between the number of nodes on a stem segment and the number of plantlets regenerated on N6 medium supplemented with three levels of kinetin (K) after 30 days of incubation (bars represent $\pm \mathrm{SE})$. apple regenerated from this nodal etiolation method.

With our method (Fig. 3), $\approx 80,000$ plantlets can be regenerated within a year from one primary plant. Although the efficiency of this method is slightly lower than the 100,000 plants produced from one shoot in $<12$ months as reported by Drew (1980), it has the advantage of avoiding wounding of the regeneration zone and preventing any callus production. Our method is similar to that used for the micropropagation of potato (Goodwin and Adisarwanto, 1980; Heszky and Nagy, 1987; Marinus, 1984; Roca et al., 1978), and the regeneration rate (plantlet per node) is about the same as with potato.

Compared to the traditional means of pineapple propagation, our method is similar to using peduncle slips and mature stumps in field culture but adapted to in vitro conditions. The omission of callus production may reduce the problem of genetic instability during multiplication.

A new method for pineapple micropropagation was elaborated using an etiolated nodal cutting technique. Etiolated shoot development from in vitro stumps were induced on an MS basal media supplemented with $10 \mu \mathrm{M}$ NAA. Plantlets were regenerated from the nodes of the etiolated shoots. The best results (13 or 15 plantlets per explant) were attained when we used N6 basal medium supplemented with 20 or $25 \mu \mathrm{M}$ kinetin or BA, respectively. Plantlets were rooted on a growth-regulator-free MS medium and transferred to the greenhouse.

\section{Literature Cited}

Aghion, D. and G. Beauchesne. 1960. Utilisation de la technique de culture sterile d'organes pour obtenir des clones d'ananas. Fruits 15:464-466.

Chu, C.C. 1978. The N6 medium and its application to anther culture of cereal crops (in Chinese), $\mathrm{p}$. 43-50. In: Proc. Symp. on Plant Tissue Cult., Science Press, Beijing.

DeWald, M.G. 1988. Production of pineapple plants in vitro. Plant Cell Rpt. 7:535-537.

Drew, R.A. 1980. Pineapple tissue culture unequaled for rapid multiplication. Queensland Agr. J. 106:447-451.

Dudits, D., L. Bögre, and J. Györgyey. 1991. Embryo development from somatic plant cells in vitro: Molecular and cellular basis. J. Cell Sci. 99:473-482.

Fitchet, M. 1985. Tissue culture of pineapples. Info. Bul. Citrus and Subtropical Fruit Res. Inst. 149:1-2.

Goodwin, P.B. and T. Adisarwanto. 1980. Propagation of potato by shoot-tip culture in petri dishes. Potato Res. 23:445-448.

Gyulai, G., J. Janovszky, E. Kiss, L. Lelik, A. Csillag, and L.E. Heszky. 1992. Callus initiation and plant regeneration from inflorescence primordia of the intergeneric hybrid Agropyron repens (L.) Beauv. x Bromus inermis Leyss. cv. nanus on a modified nutritive medium. Plant Cell Rpt. 11:266-269.

Heszky, L.E. and M. Nagy. 1987. In vitro conservation of potato germplasm in Hungary, p. 465-490. In: Y.P.S. Bajaj (ed.). Biotechnology in agriculture and forestry 3, Potato. Springer-Verlag, Berlin.

Kiss, J., L.E. Heszky, E. Kiss, and G. Gyulai. 1992. High efficiency adventive embryogenesis on somatic embryos of anther, filament and immature proembryo origin in horse-chestnut (Aesculus hippocastanum L.) tissue culture.Plant Cell Tissue Organ Cult. 30:59-64. 


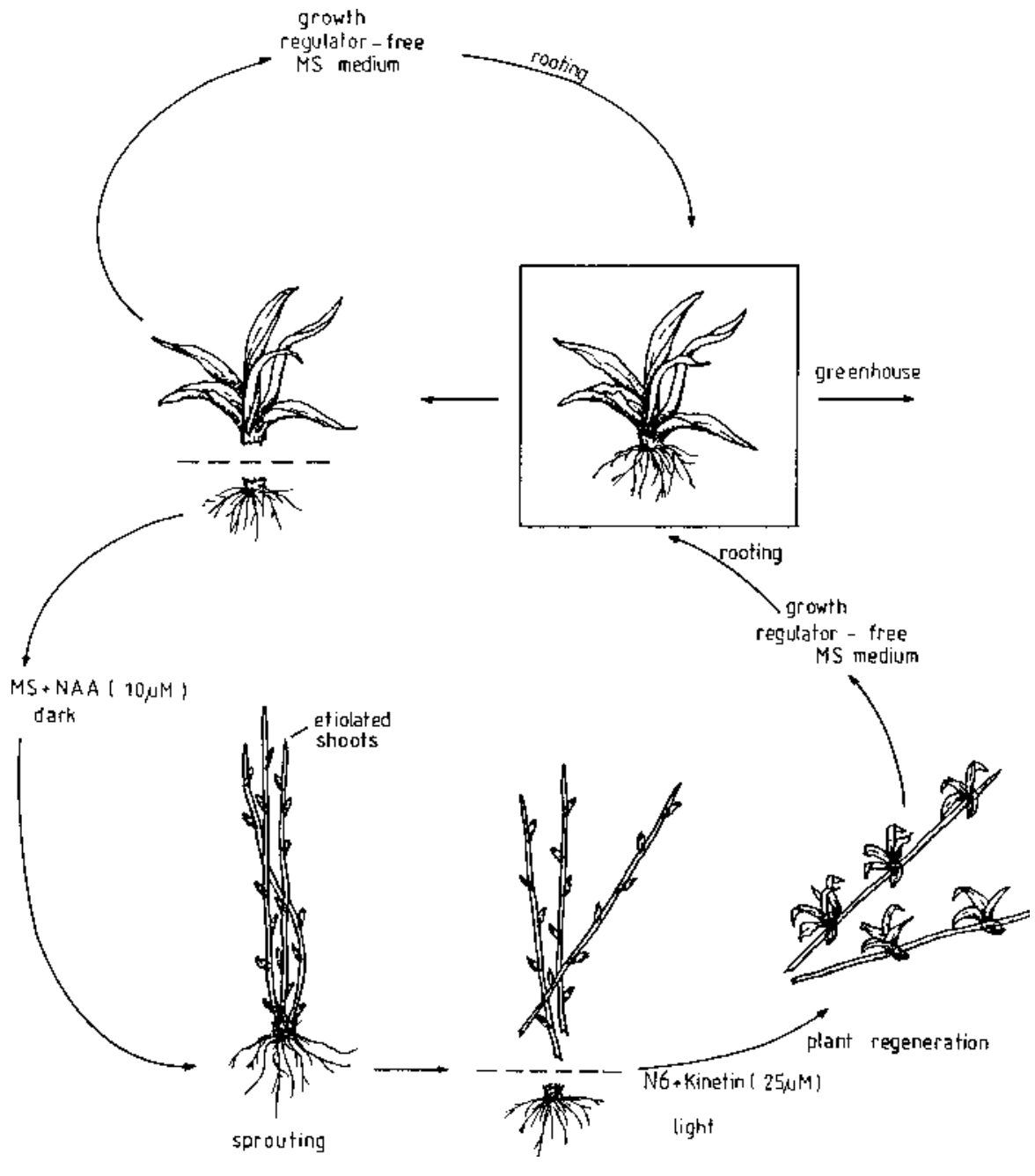

Fig. 3. Scheme of pineapple micropropagation cycle based on etiolated nodal segments.
Larkin, P.J. and W.R. Scowcroft. 1981. Somaclonal variation a novel source of variability from cell cultures for plant improvement. Theor. Appl. Genet. 60:197-214.

Maliga, P., A.S. Breznovits, L. Márton, and F. Joó. 1975. Non-mendelian streptomycin-resistant tobacco mutant with altered chloroplasts and $\mathrm{mi}-$ tochondria. Nature 225:401-402.

Mapes, M.O. 1973. Tissue culture of bromeliads. Congr. Proc. Intl. Plant Prop. Soc. 3:47-55.

Marinus, J. 1984. Methods for rapid multiplication of potatoes. Potato Res. 27:317.

Mathews, V.H., T.S. Rangan, and S. Narayanaswamy. 1976. Micropropagation of Ananas sativus in vitro. Z. Pflanzenphysiol. 79:450-454.

Murashige, T. and F. Skoog. 1962. A revised medium for rapid growth and bio-assays with tobacco tissue cultures. Physiol. Plant. 15:473-497.

Rangan, T.S. 1984. Pineapple, p. 373-382. In: P.V. Ammirato, D.A. Evans, W.R. Sharp, and Y. Yamada (eds.). Handbook of plant cell culture 3, Crop species. Macmillan, New York.

Rao, N.K.S., R.D. Swamy, and E.K. Chacko. 1981. Differentiation of plantlets in hybrid embryo callus of pineapple. Scientia Hort. 15:235-238.

Roca, W.M., N.O. Espinoza, M.R. Roca, and J.E. Bryan. 1978. A tissue culture method for the rapid propagation of potatoes. Amer. Potato $\mathrm{J}$. 55:691-706.

Seow, K.K. and Y.C. Wee. 1970. The leaf bud method of vegetative propagation in pineapple. Malay. Agr. J. 47:499-507.

Sita, L.G., R. Sing, and C.P.A. Iyer. 1974. Plantlets through shoot tip cultures in pineapple. Current Sci. 45:724-725.

Skirvin, R.M. 1981. Fruit crops, p. 51-139. In: B.V. Conger (ed.). Cloning agricultural plants via in vitro techniques. Chemical Rubber Co. Press, Boca Raton, Fla.

Wakasa, K. 1979. Variation in the plants from the tissue culture of pineapples. Jpn. J. Breeding 29:13-22.

Wee, Y.C. 1979. Mass propagation of pineapple planting materials. Singapore J. Ind. 7:24-26.

Zepeda, C. and Y. Sagawa. 1981. In vitro propagation of pineapple. HortScience 16:495. 